\title{
Epidemiological Factors Associated With Hbv Infection And Uptake Of Hbv Testing In South West Region Of Cameroon: What Can Be Done To Scale Up Hbv Testing In Our Setting?
}

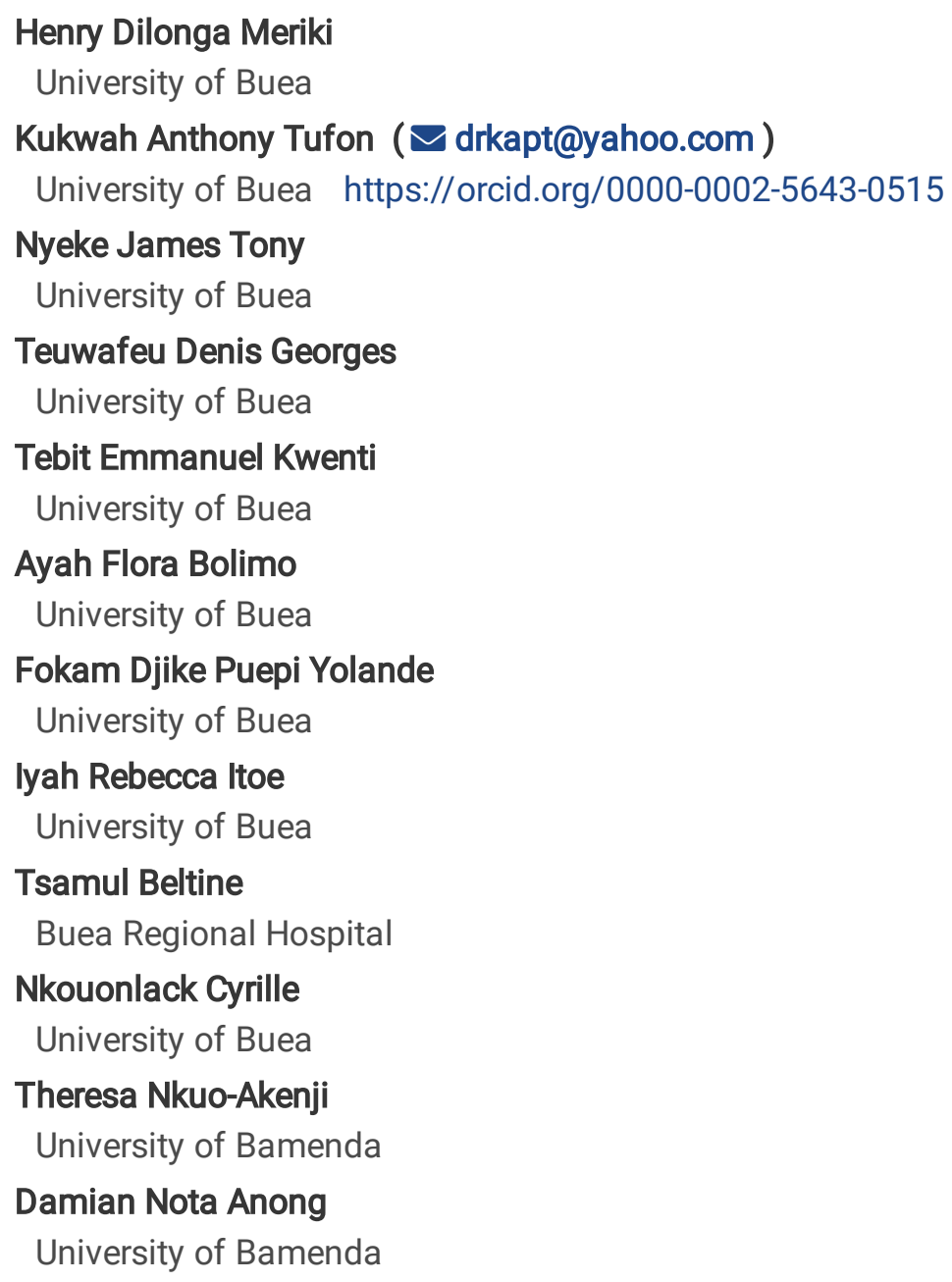

Research Article

Keywords: HBV infection, HBsAg testing, risk factors, healthy controls

Posted Date: November 9th, 2020

DOI: https://doi.org/10.21203/rs.3.rs-102313/v1

License: (9) (i) This work is licensed under a Creative Commons Attribution 4.0 International License. Read Full License 


\section{Abstract}

Background: HBV infection affects millions of people globally and this can be partly attributed to its high degree of transmissibility. This study was aimed at identifying some prevailing epidemiological factors associated with HBV infection and uptake of HBV testing in South West region of Cameroon.

Methods: This was a hospital-based case-control study which enrolled HBV infected participants and "healthy" controls $\geq 18$ years old. Venous blood collected from participants was used to conduct HBV panel test. Data on demographic and behavioral risk factors as well as reasons for doing the HBV test for the first time were collected using a questionnaire.

Results: A total of 424 participants were enrolled (212 "healthy" controls and 212 HBV infected cases). Male sex (odds ratio $[O R]=2.08, p=0.010), \leq$ secondary education level $(O R=4.83, p<0.001)$, low income level $(O R=3.79, p<0.001)$, rural settlement $(\mathrm{OR}=2.17, \mathrm{p}=0.031)$, history of sexually transmitted infections $(\mathrm{STI})(\mathrm{OR}=4.24, \mathrm{p}<0.001)$ and ignorance of sex partners HBsAg status (OR=2.70, $p=0.003)$ all had an independent and significant association with HBV infection. Top 3 reasons for doing HBsAg test were free screening (40.3\%), Blood donation (15.0\%) and administrative requirements (14.9\%). Seven (1.7\%) participants got tested for the first time after symptoms were identified by a doctor.

Conclusion: Male sex, low income level, $\leq$ secondary education level, rural settlement, history of STI and ignorance of sex partners HBsAg status were significantly associated with HBV infection. Free screening, blood donation and administrative requirements were the most common reasons for doing HBsAg test. Uptake of HBsAg testing and early detection can be improved if more sensitization and free/opportunistic screenings are carried out. A significant drop in the cost of the test could encourage more people to get tested as well.

\section{Introduction}

Over the years Hepatitis B virus (HBV) infection has remained a major public health concern with about 257 million people living with the virus [1, 2]. Its transmission is seemingly more feasible as compared to HIV and HCV although they share some similar transmission routes in common $[3,4]$. It is usually transmitted to a susceptible person when he/she comes in contact with infected blood or body fluids. The virus can remain stable on environmental surfaces even after applying simple detergents and alcohol and this further facilitates their transmission [5].

Many different transmission routes of HBV have been identified with some being more common in high endemic areas and others being more common in low endemic areas [6]. The predominant HBV transmission routes in a particular community may be dependent on the economic status as well as some cultural and behavioral activities [7] of the people which predisposes them to the infection. This study was aimed at identifying some demographic and behavioral factors associated with HBV infection in the South West region of Cameroon. Effective measures to curb HBV transmission can be easily formulated or strengthened if the prevailing associated risk factors in a particular community are known. In addition to the identification and implementation of measures to reduce HBV transmission, scaling up HBV testing could play a key role in eliminating hepatitis B by 2030 as envisaged by the World Health organization (WHO) [8, 9].

A systematic review and meta-analysis conducted in Cameroon revealed an HBV prevalence of $11.2 \%$ after considering different studies across the national territory[10]. The cumulative amount of people $(105,603)$ whose results were considered in this meta-analysis was quite small as compared to the actual population of the country (25 million)[11] and this could imply an overall low uptake of HBV testing in the country. Moreover, the asymptomatic nature of the disease in most cases [12] reduces the chances of suspecting it and as such, many infected individuals ignorantly live with it and may never see the need to get tested. Understanding the factors that can easily push someone to go in for the test in a community could help in implementing newer strategies or modifying existing strategies aimed at convincing people to take the test.

\section{Materials And Methods}




\section{Study location, design and population}

This study was conducted in the South West Region of Cameroon at the Buea Regional Hospital. HBV infected individuals and "healthy" controls ( $\geq 18$ years old) were enrolled as cases and controls respectively. A "healthy" control was considered to be any person who tested negative for HBsAg, anti-HBs and anti-HBc. HBV infected individuals were considered to be anybody positive for HBsAg and anti-HBc.

\section{Participant enrolment}

All the controls and a few HBV infected cases were enrolled during a free screening exercise (for HIV, HBV and HCV) we conducted in the Buea Regional Hospital which lasted for about 4 years. HBV infected participants were as well enrolled from people who came to the hospital for various reasons (blood donations, antenatal care, medical check-up, consultation etc) and tested positive for HBsAg. The snowball sampling technique was also used where already enrolled participants proposed and linked us to other eligible participants from among their acquaintances, friends and family members. Individuals with incomplete data were excluded from the study.

\section{Ethical considerations}

Ethical clearance for this study was obtained from The National Ethics Committee of Research for Human Health (NECRHH) in Cameroon. Administrative authorization was obtained from the South West Regional public health delegation and the administrative authorities of the Buea Regional Hospital. Each participant signed a consent form at enrolment as an approval. After obtaining an assent from the individuals concerned, a consent was as well gotten from the parents/guardians of minors who took part in this study. Participants were counselled prior to testing.

\section{Questionnaire administration and data collection}

Demographic data, behaviorally associated risk factors and reasons for doing HBV test for the first time were collected using an interviewer-based pre-tested questionnaire administered to all participants. Responses on socio-economic status and behavioral patterns were assessed and grouped as reported in other studies [13] with some modifications. Monthly income level was classified into the following categories:

(i) $>100,000$ XAF (> 200 US dollars) per month (White-collar workers consisting of salaried service personnel, professionals and self-employed business persons) (ii) < 100,000XAF (<200 US dollars) per month (Blue-collar workers, which included agricultural, non-agricultural, skilled labourers and self-employed/salaried service personnel) and (iii) no income. Level of education was grouped into $\leq$ secondary and

$>$ Secondary education. Age at first sexual intercourse was grouped into $\leq 18$ years and $>18$ years of age. The use of condom was classified into 3 different groups: Never/rarely, sometimes and always.

\section{Sample collection, processing and laboratory analysis}

Approximately $4 \mathrm{ml}$ of venous blood was collected from each participant in a dry tube (no anticoagulant). The samples were allowed to clot and then centrifuged at $3000 \mathrm{rpm}$ for 5 minutes to obtain serum. HBV serologic profile test was done using immunochromatographic panel kit (Blue Cross Bio-Medical Co. Ltd, Beijing) following manufacturer's instructions. HBsAg and anti-HBc combined positivity was used to confirm HBV infection.

\section{Statistical analysis}

Data analysis was carried out using SPSS (Statistical Package for the Social Sciences, Chicago, Illinois) version 21.0. Data were presented using frequency distribution tables and summary statistics. Categorical comparisons were performed using the Pearson's Chi-square test or the Fisher's exact test (for 2 by 2 cells having values $<5$ ). A logistic regression analysis was fitted for variables that recorded $p$-value $\leq 0.2$ in the crude odds ratio (OR). A p-value $<0.05$ was considered significant for all analyses. 


\section{Results}

A total of 424 participants were enrolled. This population was made up of 212 "healthy controls" and 212 HBV infected cases. The overall population was made up of 232 (54.7\%) females and 192 (45.3\%) males. The healthy control group recorded a mean age of $32.28 \pm 8.4$ with ages ranging from 18 to 65 years old. The positive cases recorded a mean age of $31.21 \pm 7.5$ with ages ranging from 18 to 63 years old (Table 1 )

Table 1

Age and gender distribution of participants

\begin{tabular}{|c|c|c|c|c|}
\hline Groups (n) & $\begin{array}{l}\text { Mean age } \\
\text { (years) }\end{array}$ & $\begin{array}{l}\text { Age range } \\
\text { (years) }\end{array}$ & Gender & $\mathrm{n}(\%)$ \\
\hline \multirow[t]{2}{*}{ HBV infected cases (212) } & \multirow[t]{2}{*}{$31.21 \pm 7.5$} & \multirow[t]{2}{*}{$18-63$} & Female & $94(44.3)$ \\
\hline & & & Male & $118(55.7)$ \\
\hline \multirow{2}{*}{$\begin{array}{l}\text { "Healthy" controls } \\
\text { (212) }\end{array}$} & \multirow[t]{2}{*}{$32.28 \pm 8.4$} & \multirow[t]{2}{*}{$18-65$} & Female & $138(65.1)$ \\
\hline & & & Male & $74(34.9)$ \\
\hline
\end{tabular}

Males $(O R=2.08)$, people with $\leq$ secondary level of education $(O R=4.22)$ were significantly more associated with the infection as compared to females and people with > secondary level of education respectively. People with income level $\geq$ $100,000 X A F$ and people living in urban areas proved to be significantly less associated with the infection (Table 2). 
Table 2

Demographic factors and their possible association with HBV infection

\begin{tabular}{|c|c|c|c|c|c|c|c|c|c|c|}
\hline \multicolumn{2}{|c|}{ DEMOGRAPHIC FACTORS } & \multirow[t]{3}{*}{$\mathrm{n}$} & \multirow{2}{*}{\multicolumn{2}{|c|}{ STATUS }} & \multicolumn{6}{|c|}{ RISK ESTIMATE } \\
\hline & & & & & \multicolumn{3}{|c|}{ Crude odds ratio } & \multicolumn{3}{|c|}{ Adjusted odds ratio } \\
\hline & & & Controls & Cases & $\begin{array}{l}\text { Odd } \\
\text { ratio }\end{array}$ & $\begin{array}{l}95 \% \\
\mathrm{Cl} *\end{array}$ & $\begin{array}{l}\mathrm{P}- \\
\text { value }\end{array}$ & $\begin{array}{l}\text { Odd } \\
\text { ratio }\end{array}$ & $\begin{array}{l}95 \% \\
\mathrm{Cl}\end{array}$ & $\begin{array}{l}\mathrm{P} \text { - } \\
\text { value }\end{array}$ \\
\hline \multirow[t]{2}{*}{ Gender, n (\%) } & Male & 192 & $\begin{array}{l}74 \\
(38.5)\end{array}$ & $\begin{array}{l}118 \\
(61.5)\end{array}$ & 2.34 & \multirow[t]{2}{*}{$\begin{array}{l}1.58- \\
3.46\end{array}$} & \multirow[t]{2}{*}{$\hat{0} .001$} & 2.08 & \multirow[t]{2}{*}{$\begin{array}{l}1.19- \\
3.70\end{array}$} & \multirow[t]{2}{*}{0.010} \\
\hline & Female & 232 & $\begin{array}{l}138 \\
(59.5)\end{array}$ & $\begin{array}{l}94 \\
(40.5)\end{array}$ & 1 & & & 1 & & \\
\hline \multirow[t]{2}{*}{ Age group, $\mathrm{n}(\%)$} & $\begin{array}{l}<30 \text { years } \\
\text { old }\end{array}$ & 193 & $\begin{array}{l}85 \\
(44.0)\end{array}$ & $\begin{array}{l}108 \\
(56.0)\end{array}$ & 1.55 & \multirow[t]{2}{*}{$\begin{array}{l}1.06- \\
2.28\end{array}$} & \multirow[t]{2}{*}{0.025} & 1.38 & \multirow[t]{2}{*}{$\begin{array}{l}0.74- \\
2.57\end{array}$} & \multirow[t]{2}{*}{0.310} \\
\hline & $\begin{array}{l}\geq 30 \text { years } \\
\text { old }\end{array}$ & 231 & $\begin{array}{l}127 \\
(55.0)\end{array}$ & $\begin{array}{l}104 \\
(45.0)\end{array}$ & 1 & & & 1 & & \\
\hline \multirow[t]{3}{*}{$\begin{array}{l}\text { Monthly Income } \\
\text { level, } n(\%)\end{array}$} & No income & 128 & $\begin{array}{l}49 \\
(38.3)\end{array}$ & $\begin{array}{l}79 \\
(61.7)\end{array}$ & \multirow{2}{*}{$\begin{array}{l}3.28 \\
3.90\end{array}$} & \multirow{2}{*}{$\begin{array}{l}2.05- \\
5.23 \\
\\
2.36- \\
6.43\end{array}$} & \multirow{2}{*}{$\begin{array}{l}< \\
0.001 \\
< \\
0.001\end{array}$} & & $\begin{array}{l}1.79- \\
8.05\end{array}$ & $\hat{0.001}$ \\
\hline & $\begin{array}{l}<100,000 \\
\text { XAF }\end{array}$ & 108 & $\begin{array}{l}37 \\
(34.3)\end{array}$ & $\begin{array}{l}71 \\
(65.7)\end{array}$ & & & & 1 & $\begin{array}{l}2.28- \\
6.30\end{array}$ & $\begin{array}{l}<.001 \\
0.00\end{array}$ \\
\hline & $\geq 100,000 \times A F$ & 188 & $\begin{array}{l}126 \\
(67.0)\end{array}$ & $62(33.0)$ & & & & & & \\
\hline \multirow[t]{2}{*}{$\begin{array}{l}\text { Level of education, } \\
\mathrm{n}(\%)\end{array}$} & $\leq$ Secondary & 91 & $\begin{array}{l}20 \\
(22.0)\end{array}$ & $\begin{array}{l}71 \\
(78.0)\end{array}$ & 4.83 & \multirow[t]{2}{*}{$\begin{array}{l}2.81- \\
8.31\end{array}$} & \multirow[t]{2}{*}{$\hat{0.001}$} & 4.22 & \multirow[t]{2}{*}{$\begin{array}{l}1.87- \\
9.50\end{array}$} & \multirow[t]{2}{*}{$\hat{0} .001$} \\
\hline & >Secondary & 333 & $\begin{array}{l}192 \\
(57.7)\end{array}$ & $\begin{array}{l}141 \\
(42.3)\end{array}$ & 1 & & & 1 & & \\
\hline \multirow[t]{2}{*}{$\begin{array}{l}\text { Marital status, } \\
\mathrm{n}(\%)\end{array}$} & Single & 219 & $\begin{array}{l}102 \\
(46.6)\end{array}$ & $\begin{array}{l}117 \\
(53.4)\end{array}$ & 1.41 & \multirow[t]{2}{*}{$\begin{array}{l}0.96- \\
2.07\end{array}$} & \multirow[t]{2}{*}{0.079} & 1.59 & \multirow[t]{2}{*}{$\begin{array}{l}0.99- \\
2.18\end{array}$} & \multirow[t]{2}{*}{0.094} \\
\hline & Married & 205 & $\begin{array}{l}113 \\
(55.1)\end{array}$ & $\begin{array}{l}92 \\
(44.9)\end{array}$ & 1 & & & 1 & & \\
\hline \multirow[t]{2}{*}{$\begin{array}{l}\text { Type of school } \\
\text { attended, n(\%) }\end{array}$} & $\begin{array}{l}\text { Boarding } \\
\text { school }\end{array}$ & 102 & $\begin{array}{l}60 \\
(58.8)\end{array}$ & $\begin{array}{l}42 \\
(41.2)\end{array}$ & 0.67 & \multirow[t]{2}{*}{$\begin{array}{l}0.42- \\
1.05\end{array}$} & \multirow[t]{2}{*}{0.077} & 0.58 & $\begin{array}{l}0.29- \\
1.16\end{array}$ & 0.122 \\
\hline & Days school & 322 & $\begin{array}{l}157 \\
(48.8)\end{array}$ & $\begin{array}{l}165 \\
(51.2)\end{array}$ & 1 & & & 1 & & \\
\hline $\begin{array}{l}\text { Area of Residence, } \\
\mathrm{n}(\%)\end{array}$ & Rural & 133 & $\begin{array}{l}51 \\
(38.3)\end{array}$ & $\begin{array}{l}82 \\
(61.7)\end{array}$ & 2.32 & $\begin{array}{l}1.53- \\
3.54\end{array}$ & $<0.001$ & 2.17 & $\begin{array}{l}1.32- \\
3.40\end{array}$ & 0.031 \\
\hline & Urban & 291 & $\begin{array}{l}172 \\
(59.1)\end{array}$ & $\begin{array}{l}119 \\
(40.9)\end{array}$ & 1 & & & 1 & & \\
\hline
\end{tabular}

Individuals with a history/presence of other sexually transmitted infections (gonorrhoea, syphilis, chlamydia, HIV etc) were more associated with HBV infection recording a statistically significant difference $(p<0.001)$ in both the crude and adjusted odds ratio (Table 3 ). 
Table 3

Some behavioural factors and their possible association with HBV infection

\begin{tabular}{|c|c|c|c|c|c|c|c|c|c|c|}
\hline \multicolumn{2}{|c|}{ BEHAVIOURAL FACTORS } & \multirow[t]{3}{*}{$\mathrm{n}$} & \multirow{2}{*}{\multicolumn{2}{|c|}{ STATUS }} & \multicolumn{6}{|c|}{ RISK ESTIMATE } \\
\hline & & & & & \multicolumn{3}{|c|}{ Crude odds ratio } & \multicolumn{3}{|c|}{ Adjusted odds ratio } \\
\hline & & & Controls & Cases & $\begin{array}{l}\text { Odd } \\
\text { ratio }\end{array}$ & $95 \% \mathrm{Cl}$ & $\begin{array}{l}\mathrm{P} \text { - } \\
\text { value }\end{array}$ & $\begin{array}{l}\text { Odd } \\
\text { ratio }\end{array}$ & $(95 \% \mathrm{Cl})$ & $\begin{array}{l}\text { P- } \\
\text { value }\end{array}$ \\
\hline \multirow{2}{*}{$\begin{array}{l}\text { Age at first } \\
\text { sexual } \\
\text { intercourse*n(\%) }\end{array}$} & $\begin{array}{l}\leq 18 \text { years } \\
\text { old }\end{array}$ & 150 & $\begin{array}{l}51 \\
(34.0)\end{array}$ & $99(66.0)$ & 2.58 & \multirow[t]{2}{*}{$\begin{array}{l}1.70- \\
3.92\end{array}$} & \multirow[t]{2}{*}{ <. 001} & 1.78 & \multirow[t]{2}{*}{$\begin{array}{l}1.00- \\
3.14\end{array}$} & \multirow[t]{2}{*}{0.051} \\
\hline & $\begin{array}{l}>18 \text { years } \\
\text { old }\end{array}$ & 254 & $\begin{array}{l}145 \\
(57.1)\end{array}$ & $\begin{array}{l}109 \\
(42.9)\end{array}$ & 1 & & & 1 & & \\
\hline \multirow{2}{*}{$\begin{array}{l}\text { History/presence } \\
\text { of other STIs * } \\
n(\%)\end{array}$} & Yes & 56 & $\begin{array}{l}11 \\
(19.6)\end{array}$ & $45(80.4)$ & 4.64 & \multirow[t]{2}{*}{$\begin{array}{l}2.32- \\
9.28\end{array}$} & \multirow[t]{2}{*}{$\hat{0} .001$} & 4.24 & \multirow[t]{2}{*}{$\begin{array}{l}1.75- \\
10.29\end{array}$} & \multirow[t]{2}{*}{ <. 001} \\
\hline & No & 348 & $\begin{array}{l}185 \\
(53.2)\end{array}$ & $\begin{array}{l}163 \\
(46.8)\end{array}$ & 1 & & & 1 & & \\
\hline \multirow[t]{3}{*}{$\begin{array}{l}\text { Use of condom* } \\
n(\%)\end{array}$} & Rarely/never & 197 & $\begin{array}{l}93 \\
(47.2)\end{array}$ & $\begin{array}{l}104 \\
(52.8)\end{array}$ & \multirow{3}{*}{$\begin{array}{l}0.72 \\
0.49 \\
1\end{array}$} & \multirow{3}{*}{$\begin{array}{l}0.42- \\
1.23 \\
0.27- \\
0.86\end{array}$} & \multirow{3}{*}{$\begin{array}{l}0.230 \\
\mathbf{0 . 0 1 4}\end{array}$} & 0.47 & \multirow[t]{3}{*}{$\begin{array}{l}0.26- \\
0.85\end{array}$} & \multirow[t]{3}{*}{0.010} \\
\hline & Sometimes & 128 & $\begin{array}{l}73 \\
(57.0)\end{array}$ & $55(43.0)$ & & & & & & \\
\hline & Always & 79 & $\begin{array}{l}31 \\
(39.2)\end{array}$ & $48(60.8)$ & & & & & & \\
\hline \multirow{2}{*}{$\begin{array}{l}\text { Ritual } \\
\text { scarification? } \\
\mathrm{n}(\%)\end{array}$} & Yes & 229 & $\begin{array}{l}119 \\
(52.0)\end{array}$ & $\begin{array}{l}110 \\
(48.0)\end{array}$ & 0.84 & \multirow[t]{2}{*}{$\begin{array}{l}0.58- \\
1.24\end{array}$} & \multirow[t]{2}{*}{0.381} & & & \\
\hline & No & 195 & $\begin{array}{l}93 \\
(47.7)\end{array}$ & $\begin{array}{l}102 \\
(52.3)\end{array}$ & 1 & & & & & \\
\hline \multirow{2}{*}{$\begin{array}{l}\text { Practice } \\
\text { roadside } \\
\text { manicure and } \\
\text { pedicure, } \mathrm{n}(\%)\end{array}$} & Yes & 55 & $\begin{array}{l}34 \\
(61.8)\end{array}$ & $21(38.2)$ & 0.58 & \multirow[t]{2}{*}{$\begin{array}{l}0.32- \\
1.03\end{array}$} & \multirow[t]{2}{*}{0.062} & 0.69 & \multirow[t]{2}{*}{$\begin{array}{l}0.32- \\
1.45\end{array}$} & \multirow[t]{2}{*}{0.225} \\
\hline & No & 369 & $\begin{array}{l}178 \\
(48.2)\end{array}$ & $\begin{array}{l}191 \\
(51.8)\end{array}$ & 1 & & & 1 & & \\
\hline \multirow{2}{*}{$\begin{array}{l}\text { Ever had a blood } \\
\text { transfusion? } \\
\mathrm{n}(\%)\end{array}$} & Yes & 19 & $7(36.8)$ & $12(63.2)$ & 1.76 & \multirow{2}{*}{$\begin{array}{l}0.68- \\
4.55\end{array}$} & \multirow[t]{2}{*}{0.246} & & & \\
\hline & No & 405 & $\begin{array}{l}205 \\
(50.6)\end{array}$ & $200(49.4)$ & 1 & & & & & \\
\hline \multirow[t]{2}{*}{ Tattoo, n(\%) } & Yes & 8 & $3(37.5)$ & $5(62.5)$ & 1.68 & $0.40-$ & 0.480 & & & \\
\hline & No & 416 & $\begin{array}{l}209 \\
(50.2)\end{array}$ & $\begin{array}{l}207 \\
(49.8)\end{array}$ & 1 & & & & & \\
\hline $\begin{array}{l}\text { Knowledge of } \\
\text { sexual partner's } \\
\text { HBsAg status* }\end{array}$ & $\begin{array}{l}\text { Knows } \\
\text { partner is } \\
\text { Positive }\end{array}$ & 80 & $\begin{array}{l}58 \\
(72.5)\end{array}$ & $22(27.5)$ & 0.28 & $\begin{array}{l}0.17- \\
0.49\end{array}$ & <. 0.001 & 0.37 & $\begin{array}{l}0.20- \\
0.71\end{array}$ & 0.003 \\
\hline & $\begin{array}{l}\text { Don't } \\
\text { know/knows } \\
\text { partner is } \\
\text { Negative }\end{array}$ & 217 & $\begin{array}{l}139 \\
(42.9)\end{array}$ & $\begin{array}{l}1185 \\
(57.1)\end{array}$ & 1 & & & 1 & & \\
\hline
\end{tabular}

People who knew that their sexual partners were HBsAg positive were significantly less associated with the infection as compared to those who did not know their sexual partner's status and those who knew their partners were HBsAg negative. This observation was statistically significant in both the crude and adjusted odds ratio (Table 3). 
Table 2: Demographic factors and their possible association with HBV infection

Table 3: Some behavioural factors and their possible association with HBV infection

The top 3 reasons for getting tested for the first time were free screening (40.3\%), Blood donation (15.0\%) and administrative requirements (14.9\%) as seen in Fig. 1. One hundred and seventy-one participants admitted doing HBV test for the first time during free screening exercises. Of these 171 participants, 93 (54.4\%) admitted being screened for the first time by us.

Figure 1: Reasons for first ever HBV screening for all participants $(n=424)$

Average age at first HBV testing was highest for those who tested following pre-marital recommendations (32.1 \pm 6.4 years). Age range at first HBV testing was widest (15-65 years) for those who tested for the first time during free screenings (Table 4).

Table 4

Distribution of gender and age at first HBV testing across various testing reasons

\begin{tabular}{|c|c|c|c|c|c|c|}
\hline \multirow[t]{2}{*}{ Reason for first HBV testing (n) } & \multirow[t]{2}{*}{ Gender } & \multirow[t]{2}{*}{$\mathrm{n}(\%)$} & \multicolumn{4}{|c|}{ Age at first HBV testing (years) } \\
\hline & & & Mean \pm SD & Range & Median & $\mathrm{IQR}^{*}$ \\
\hline \multirow[t]{2}{*}{ Free screening (171) } & Female & $114(66.7)$ & \multirow[t]{2}{*}{$29.8 \pm 7.8$} & \multirow[t]{2}{*}{$16-65$} & \multirow[t]{2}{*}{29.0} & \multirow[t]{2}{*}{11} \\
\hline & Male & 57 (33.3) & & & & \\
\hline \multirow[t]{2}{*}{ Blood donation (64) } & Female & $14(21.9)$ & \multirow[t]{2}{*}{$26.8 \pm 7.7$} & \multirow[t]{2}{*}{$20-41$} & \multirow[t]{2}{*}{25.0} & \multirow[t]{2}{*}{10} \\
\hline & Male & $50(78.1)$ & & & & \\
\hline \multirow[t]{2}{*}{ Sickness (7) } & Female & $3(42.9)$ & \multirow[t]{2}{*}{$26.3 \pm 8.0$} & \multirow[t]{2}{*}{$15-39$} & \multirow[t]{2}{*}{26.0} & \multirow[t]{2}{*}{19} \\
\hline & Male & $4(57.1)$ & & & & \\
\hline \multirow[t]{2}{*}{ Pre-vaccination (37) } & Female & $20(54.1)$ & \multirow[t]{2}{*}{$30.5 \pm 9.40$} & \multirow[t]{2}{*}{$18-54$} & \multirow[t]{2}{*}{30.0} & \multirow[t]{2}{*}{12} \\
\hline & Male & $17(45.9)$ & & & & \\
\hline \multirow[t]{2}{*}{ Pre-marital (33) } & Female & $13(39.4)$ & \multirow[t]{2}{*}{$32.1 \pm 6.4$} & \multirow[t]{2}{*}{$22-43$} & \multirow[t]{2}{*}{32.5} & \multirow[t]{2}{*}{7} \\
\hline & Male & $20(60.6)$ & & & & \\
\hline \multirow[t]{2}{*}{ Administrative (63) } & Female & $9(14.3)$ & \multirow[t]{2}{*}{$26.1 \pm 5.54$} & \multirow[t]{2}{*}{$20-40$} & \multirow[t]{2}{*}{23.0} & \multirow[t]{2}{*}{8} \\
\hline & Male & 54 (85.7) & & & & \\
\hline \multirow[t]{2}{*}{ Antenatal (49) } & Female & 49 (100) & \multirow[t]{2}{*}{$26.1 \pm 5.04$} & \multirow[t]{2}{*}{$18-37$} & \multirow[t]{2}{*}{25.0} & 7 \\
\hline & Male & - & & & & \\
\hline
\end{tabular}

Only $6(2.6 \%)$ of the HBV infected individuals got to know their status because of ill health (probable presentation of some signs and symptoms which made the doctor to demand HBsAg test). Forty-eight (22.5\%) of them got to know their status because they wanted to donate blood (Fig. 2). Free screening accounted for $31.7 \%$ of all the identified HBV infected cases in our study.

Figure 2: Reasons for first HBV testing for HBV infected cases $(n=212)$

\section{Discussion}


Our study showed that males were more associated with HBV infection as compared to females. This has been established in previous studies $[12,14,15]$ and could be attributed to hormonal and some protein expression differences. Oestrogen has been shown to play a protective role in females at reproductive age [16-18]. Some particular unusual apolipoprotein (A-I) found only on the hepatocytes of males have been shown to predispose them to the infection and its associated complications [19].

People with no income or with a monthly income of $<100,000 \mathrm{XAF}$ were more associated with the infection as compared to people with $\geq 100,000 X A F$ monthly income as seen in another study [20]. We could attribute this to the fact that people who earn more money can easily have access to the best and safest health practices (afford vaccines for instance) and life style that would limit their contact or the possibilities of them sharing objects/materials that may have been contaminated. Low income level have been shown to be a major characteristic of people living in rural areas both in Cameroon [21] and other parts of the world [22-25]. Our study also showed that people who live in rural areas were significantly more associated with HBV infection as compared to those in urban areas as seen in other studies [10,26-28]. Poverty, high level of illiteracy, limited knowledge on preventive care, poor access to health care and dearth of sensitization may all account for the poor health outcomes in rural areas $[25,29]$.

Participants with $\leq$ secondary level of education were independently and significantly associated with HBV infection. Some other studies [30-32] have recorded similar findings. People with higher educational attainment tend to live a healthier live as compared to those with little or no educational background [33]. Routine comprehensive health talks on HBV infection in primary and secondary schools could help to curb the transmission of HBV in our community as this would guarantee youth awareness of the infection and its preventive measures during the early stages of their academic lives.

Individuals with a history/presence of other sexually transmitted infections (STI) were significantly associated with HBV infection in our study population. This was also noticed in other studies [34, 35]. Despite all the identified sexual risk behaviours, our study instead showed that people who always use condoms were more associated with HBV infection. Some of the participants who "claimed" to be loyal users of condom also admitted having contracted at least one STI (chlamydia infection, gonorrhoea, syphilis etc) before in their lives and this gives us every reason to doubt their response or doubt their knowledge on proper use of condoms. Unfortunately, our study did not get into the details of assessing knowledge and practise of proper use of condoms. Assessment of sexual risk behaviours is usually very challenging because some people tend to be very reserved and shy when it comes to presenting the truth about their sexual life even for research purpose where there is a guarantee of confidentiality and no disclosure of identity [36, 37]. Interestingly, we realised that participants who knew their sexual partners were positive for HBV infection were independently and significantly not associated with the infection as compared to those who knew their partners were negative and those who did not know the status of their sexual partners. This tells us that people who knew their partners were HBsAg positive probably took adequate precautions like getting vaccinated, practising safe sex etc to ensure that they do not contract the infection themselves over time. People who did not know their partner's status or knew that their partners were HBsAg negative probably paid less attention to safety precautions and/or vaccination against the infection over time.

History of blood transfusion was not associated with HBV infection in this study. This was observed in other studies as well $[14,38-40]$ but one study conducted in the North West Region of Cameroon [31] found an association. As a result of better diagnostic and screening methods of Transfusion Transmitted Infections (TTI) prior to blood transfusion, HBV transmission via this route seems to be decreasing over time [41]. The careful and meticulous screening of donor's blood usually disqualifies many donors due to HBsAg positivity. Our study further throws more light on this as blood donation was recorded as the second most common reason why our participants got tested for the first time and this exercise alone detected HBV infection in 48 (22.5\%) of the 212 HBV infected participants.

The third most common reason for HBV screening in this study was subjection to some obligatory administrative requirements (14.9\%). This includes requirements for a job acquisition, immigration, academic admissions etc. If these obligatory testing requirements where not applicable, some of the people in this particular group could have still been 
ignorant of their status even up till date. The idea of subjecting people to an obligatory testing as an administrative requirement can help improve uptake of HBV testing. However, because most of such institutions are not healthcare institutions, we cannot guarantee if they consider linking people to care (for those who test HBsAg positive) or vaccine acquisition (for those who test HBsAg negative) after testing as per the recommendations of WHO [42].

Thirty-seven (only $8.7 \%$ ) of our participants got tested for the first time because they wanted to receive the HBV vaccine. HBV pre-vaccination testing (HBsAg or anti-HBc) is usually recommended for people in high risk groups (healthcare workers, sexual and household contacts of HBV infected persons etc) and for foreigners born in HBV endemic areas as per CDC[43]. It could be quite important for this recommendation to as well include natives of HBV endemic regions like Cameroon as this would help improve uptake of HBV testing as well as identify those who do not need the vaccine because of a current infection or presence of an already developed natural immunity to the infection. Identifying such people prior to vaccination can be cost effective on their part as they would not have to pay for a vaccine they don't need. The cost of taking the complete vaccine is way more expensive than the cost of doing the test in Cameroon.

Only $7(1.7 \%)$ participants got tested for the first time as a result of sickness or clinical manifestations which could make the doctor to suspect HBV infection. The long-term asymptomatic nature of the disease greatly influences the number of people who end up getting tested as doctors seldom request for the test. As such, many infected cases go undetected and their ignorance could promote disease progression and further transmission to other uninfected susceptible people. In order to improve on the uptake of HBV tests in hospitals even in the absence of corroborative signs and symptoms of HBV infection, medical doctors could as well propose the test as some form of opportunistic screening [44] to every patient they attend to. This is a strategy that is currently being implemented to scale up HIV testing in Cameroon as approved by the public health sector. Considering the fact that HBV is more prevalent than HIV in our population and also the fact that HBV and HIV infection are both major public health problems, it could be helpful to as well adopt and encourage the hospital opportunistic screening strategy for HBV in Cameroon.

Voluntarily taking part in a free screening exercise was the most common reason for doing HBV test for the first time in this study. As a matter of fact, 93 (54.4\%) participants did HBsAg test for their first time during our free screening exercise. The widest age range (16-65 years) at first HBsAg test was also found in this group of people. The significant proportion from our free screening was quite evident because the exercise lasted for long (about 4 years) and as such, could cover more people over time. However, the "free screening exercise" pretext as a reason for HBV testing may have been overrated in this study because our screening period just might have presented itself at a time when some participants realised the importance of doing the test for various reasons (pre-marital, pre-vaccine etc) but chose not to disclose these reasons to us. Another issue worth addressing here is the cost of doing HBsAg test. Although HBV infection happens to be more prevalent as compared to HIV in our community, HBsAg test is more expensive than HIV test. "Free screening exercises" are usually free of charge and this aspect alone is a huge motivation for people to voluntarily subject themselves to it. Considering the fact that Cameroon is classified as a lower middle-income country according to world bank and also the fact that our study revealed an association between low income and HBV infection, a practical approach to detect more HBV infected people in our community could be to significantly lower the cost of the test or to offer the test free of charge.

In conclusion, male sex, low income level, rural settlement, ssecondary level of education, history of STI and ignorance of sex partners HBsAg status were all significantly associated with HBV infection. Free screening, blood donation and administrative requirements were the most common reasons for HBV testing in our study population. Sensitization even at the level of primary and secondary schools could help educate the population early enough to prevent transmission. Uptake of HBV testing and early detection can be improved if more (prolonged) free/opportunistic screenings are carried out and if the health sector subsidizes the cost of the test significantly as a means to encourage people to get tested.

\section{Abbreviations}

HBV-Hepatitis B virus 
HBsAg-Hepatitis B surface antigen

HCV-Hepatitis C virus

HIV-Human immunodeficiency virus

STI-Sexually transmitted infections

WHO-World Health Organization

TTI- Transfusion Transmitted Infections

NECRHH -National Ethics Committee of Research for Human Health

XAF- Central African CFA Franc

OR-Odds ratio

\section{Declarations}

\section{Ethics approval and consent to participate}

Ethical clearance for this study was obtained from The National Ethics Committee of Research for Human Health (NECRHH) in Cameroon. Administrative authorization was obtained from the South West Regional public health delegation and the administrative authorities of the Buea Regional Hospital. Each participant signed a consent form at enrolment as an approval. After obtaining an assent from the individuals concerned, a consent was as well gotten from the parents/guardians of minors who took part in this study. Participants were counselled prior to testing.

\section{Consent for publication}

Not applicable

\section{Availability of data and materials}

The datasets generated and/or analysed during the current study are not publicly available due to the fact that it contains information which may reveal the identity of our participants. However, it can be obtained from the corresponding author upon reasonable request.

\section{Competing interests}

The authors declare that they have no competing interests

\section{Funding}

Not applicable

\section{Authors' contributions}

HDM and KAT drafted and wrote the manuscript

HDM, KAT, NJT, IRI, TB and AFB conducted the laboratory analysis

KAT and TEK carried out the statistical analysis

TDG, FDPY, NC, TEK, TNA and DNA reviewed the manuscript 
TNA and DNA supervised the research

\section{Acknowledgements}

Special thanks go to all the participants in this study. We would also like to thank the management of Buea regional Hospital, Buea, South West region, Cameroon for their support throughout the study.

\section{References}

1. Hepatitis B. fact sheets https://www.who.int/news-room/fact-sheets/detail/hepatitis-b.

2. Razavi-Shearer D, Gamkrelidze I, Nguyen MH, Chen D-S, Van Damme P, Abbas Z, Abdulla M, Abou Rached A, Adda D, Aho I, Akarca U, Hasan F, Al Lawati F, Al Naamani K, Al-Ashgar HI, Alavian SM, Alawadhi S, Albillos A, Al-Busafi SA, Aleman S, Alfaleh FZ, Aljumah AA, Anand AC, Anh NT, Arends JE, Arkkila P, Athanasakis K, Bane A, Ben-Ari Z, Berg T, et al. Global prevalence, treatment, and prevention of hepatitis B virus infection in 2016: a modelling study. Lancet Gastroenterol Hepatol. 2018;3:383-403.

3. CDC. Recommendations for Preventing Transmission of Human Immunodeficiency Virus and Hepatitis B Virus to Patients During Exposure-Prone Invasive Procedures. MMWR Morb Mortal Wkly Rep. 1991;40:1-9.

4. HIV/AIDS and Hepatitis B Coinfection http://www.hepb.org/what-is-hepatitis-b/hivaids-co-infection/.

5. Beltrami EM, Williams IT, Shapiro CN, Chamberland ME. Risk and Management of Blood-Borne Infections in Health Care Workers. Clin Microbiol Rev. 2000;13:385-407.

6. Komatsu H, Inui A, Fujisawa T. The Role of Body Fluids in the Horizontal Transmission of Hepatitis B Virus via Household/Close Contact. Eur Med J. 2016;1:67-75.

7. Hou J. Epidemiology and Prevention of Hepatitis B Virus Infection. Int J Med Sci. 2005;2:50-7.

8. WHO. Combating hepatitis B and C to reach elimination by 2030. World Heal Organ 2016(May):1-16.

9. Hellard ME, Chou R, Easterbrook P. WHO guidelines on testing for hepatitis B and C - meeting targets for testing. BMC Infect Dis. 2017;17:703.

10. Bigna JJ, Amougou MA, Asangbeh SL, Kenne AM, Noumegni SRN, Ngo-Malabo ET, Noubiap JJ: Seroprevalence of hepatitis B virus infection in Cameroon: a systematic review and meta-analysis. BMJ Open 2017, 7:e015298.

11. Cameroon Population (2019) - Worldometers https://www.worldometers.info/world-population/cameroon-population/.

12. Tufon KA, Anong DN, Meriki HD, Georges TD, Maurice M, Kouanou YS, Bolimo AF, Tony NJ, Kwenti TE, Wung NH, NkuoAkenji T. Characterization and assessment of HBV chronically infected patients: Identification of those eligible for treatment in the South West region of Cameroon. PLoS One. 2018;13:e0203312.

13. Fezeu L, Minkoulou E, Balkau B, Kengne A-P, Awah P, Unwin N, Alberti GK, Mbanya J-C. Association between socioeconomic status and adiposity in urban Cameroon. Int J Epidemiol. 2006;35:105-11.

14. Allain J-P, Candotti D, Soldan K, Sarkodie F, Phelps B, Giachetti C, Shyamala V, Yeboah F, Anokwa M, Owusu-Ofori S, Opare-Sem O. The risk of hepatitis B virus infection by transfusion in Kumasi, Ghana. Blood. 2003;101:2419-25.

15. Stroffolini T, Esvan R, Biliotti E, Sagnelli E, Gaeta GB, Almasio PL. Gender differences in chronic HBsAg carriers in Italy: Evidence for the independent role of male sex in severity of liver disease. J Med Virol. 2015;87:1899-903.

16. You H, Kong Y, Hou J, Wei L, Zhang Y, Niu J, Han T, Ou X, Dou X, Shang J, Tang H, Xie Q, Ding H, Ren H, Xu X, Xie W, Liu $X, X u$ Y, Li Y, Li J, Chow S-C, Zhuang H, Jia J. Female gender lost protective effect against disease progression in elderly patients with chronic hepatitis B. Sci Rep. 2016;6:37498.

17. Baig S. Gender disparity in infections of Hepatitis B virus. J Coll Physicians Surg Pak. 2009;19:598-600.

18. Shimizu I, Kohno N, Tamaki K, Shono M, Huang H-W, He J-H, Yao D-F. Female hepatology: favorable role of estrogen in chronic liver disease with hepatitis B virus infection. World J Gastroenterol. 2007;13:4295-305. 
19. Yang F, Yin Y, Wang F, Zhang L, Wang Y, Sun S. An Altered Pattern of Liver Apolipoprotein A-I Isoforms Is Implicated in Male Chronic Hepatitis B Progression. J Proteome Res. 2010;9:134-43.

20. Stuver SO, Boschi-Pinto C, Trichopoulos D. Infection with hepatitis B and C viruses, social class and cancer. IARC SCi Pub/ 1997:319-24.

21. Fambon S. Comparisons of Urban and Rural Poverty Determinants in Cameroon New Proposal. 2014.

22. Zhu Z, Li Z, Liu Y, Chen H, Zeng J. The impact of urban characteristics and residents' income on commuting in China. Transp Res Part D Transp Environ. 2017;57:474-83.

23. Commins P. Poverty and social exclusion in rural areas. Sociol Ruralis. 2004;44:1-6.

24. O'Hare WP. The Forgotten Fifth Child Poverty in Rural America. 2009.

25. Blumenthal SJ, Kagen J. The Effects of Socioeconomic Status on Health in Rural and Urban America. JAMA. 2002;287:109.

26. Liua J, Lvb J, Yanb B, Fengb Y, Songb L, Xub A. Comparison between two population-based hepatitis B serosurveys with an 8-year interval in Shandong Province, China. Int J Infect Dis. 2017;61:13-9.

27. Malungu Ngaira JA, Kimotho J, Mirigi I, Osman S, Ng'ang'a Z, Lwembe R, Ochwoto M. Prevalence, awareness and risk factors associated with Hepatitis $B$ infection among pregnant women attending the antenatal clinic at Mbagathi District Hospital in Nairobi, Kenya. Pan Afr Med J 2016, 24.

28. Bigna JJ, Nkeck JR, Ngouo A, Nyaga UF, Noubiap JJ. Hepatitis B virus and HIV coinfection among adults residing in Cameroon: A systematic review and meta-analysis of prevalence studies. Infect Dis Heal. 2018;23:170-8.

29. Li J, Shi L, Liang H, Ding G, Xu L. Urban-rural disparities in health care utilization among Chinese adults from 1993 to 2011. BMC Health Serv Res. 2018;18:102.

30. Han Z, Yin Y, Zhang Y, Ehrhardt S, Thio CL, Nelson KE, Bai X, Hou H. Knowledge of and attitudes towards hepatitis B and its transmission from mother to child among pregnant women in Guangdong Province, China. PLoS One.

2017;12:e0178671.

31. Abongwa LE, Kenneth P. Assessing Prevalence and Risk Factors of Hepatitis B Surface antigen amongst pregnant woman attending antenatal clinic in the North West region of Cameroon. Eur J Res Med Sci. 2016;4:32-43.

32. Jimenez AP, El-Din NS, El-Hoseiny M, El-Daly M, Abdel-Hamid M, El Aidi S, Sultan Y, El-Sayed N, Mohamed MK, Fontanet A. Community transmission of hepatitis B virus in Egypt: results from a case-control study in Greater Cairo. Int $J$ Epidemiol. 2009;38:757-65.

33. Zajacova A, Lawrence EM. The Relationship Between Education and Health: Reducing Disparities Through a Contextual Approach. Annu Rev Public Health. 2018;39:273-89.

34. Vassilev ZP, Hagan H, Lyubenova A, Tomov N, Vasilev G, Krasteva D, Des Jarlais DC. Needle exchange use, sexual risk behaviour, and the prevalence of HIV, hepatitis $B$ virus, and hepatitis $C$ virus infections among Bulgarian injection drug users. Int J STD AIDS. 2006;17:621-6.

35. Shahnaz S, Reza B, Seyed-Moayed A. Risk Factors in Chronic Hepatitis B Infection: A Case-control Study. Hepat Mon. 2005;5:109-15.

36. Schroder KEE, Carey MP, Vanable PA. Methodological challenges in research on sexual risk behavior: II. Accuracy of selfreports. Ann Behav Med. 2003;26:104-23.

37. Fenton KA, Johnson AM, McManus S, Erens B. Measuring sexual behaviour: methodological challenges in survey research. Sex Transm Infect. 2001;77:84-92.

38. Yuen M-F, Wong DK-H, Lee C-K, Tanaka Y, Allain J-P, Fung J, Leung J, Lin C-K, Sugiyama M, Sugauchi F, Mizokami M, Lai C-L. Transmissibility of hepatitis B virus (HBV) infection through blood transfusion from blood donors with occult HBV infection. Clin Infect Dis. 2011;52:624-32.

39. Frambo AAB, Atashili J, Fon PN, Ndumbe PM. Prevalence of HBsAg and knowledge about hepatitis B in pregnancy in the Buea Health District, Cameroon: a cross-sectional study. BMC Res Notes. 2014;7:394.

Page $12 / 16$ 
40. Seo DH, Whang DH, Song EY, Han KS. Occult hepatitis B virus infection and blood transfusion. World J Hepatol. 2015;7:600-6.

41. Niederhauser C. Reducing the risk of hepatitis B virus transfusion-transmitted infection. J Blood Med. 2011;2:91-102.

42. WHO. Guidelines on Hepatitis B and C Testing. 2017(February).

43. CDC. Appendix A: Immunization Management Issues. MMWR Recomm Reports 2006, 55.

44. ASHM. Hepatitis B and Primary Care Providers. 2012:1-13.

\section{Figures}

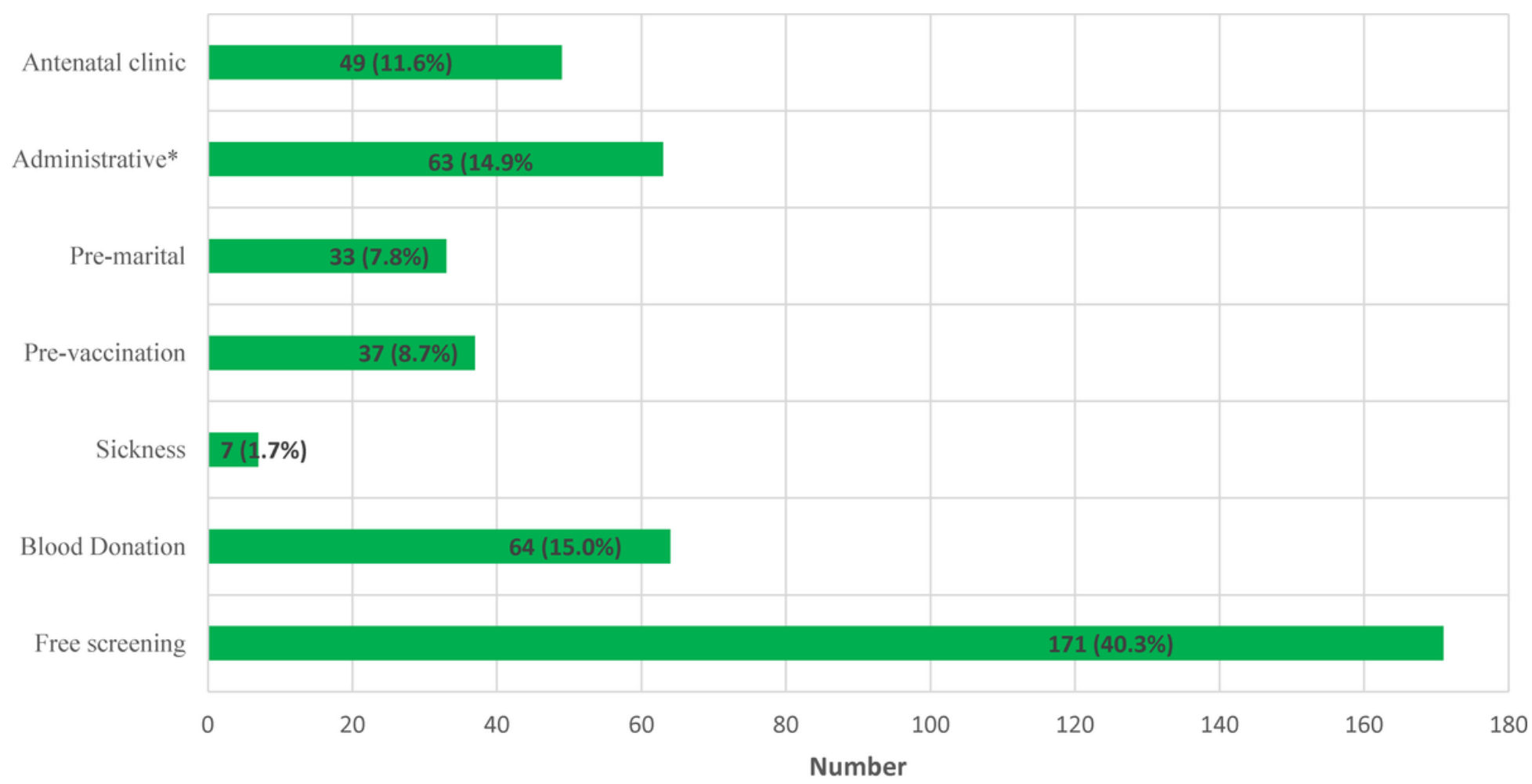

*Mandatory requirements for a job acquisition, immigration and academic admissions

\section{Figure 1}

Reasons for first ever HBV screening for all participants $(n=424)$ 
Antenatal clinic

Administrative*

Pre-marital

Pre-vaccination

Sickness

Blood Donation

Free screening
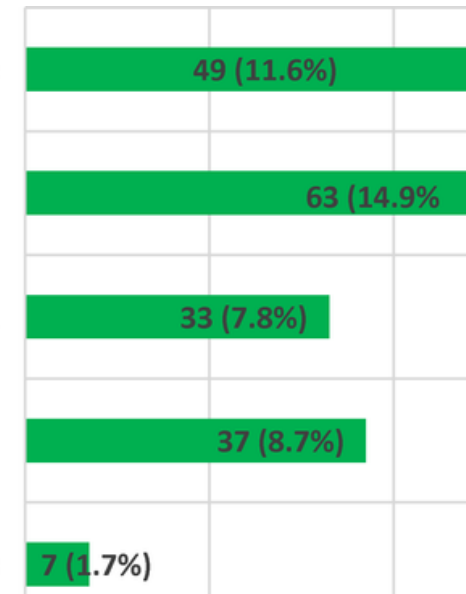

$7(1.7 \%)$

$$
\text { n }
$$

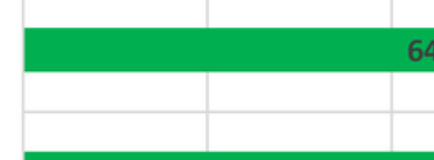

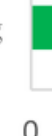

0

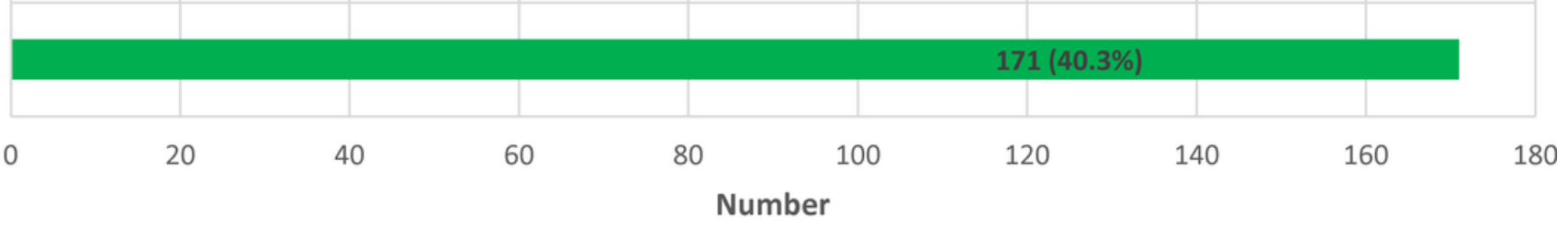

*Mandatory requirements for a job acquisition, immigration and academic admissions

\section{Figure 1}

Reasons for first ever HBV screening for all participants $(n=424)$ 


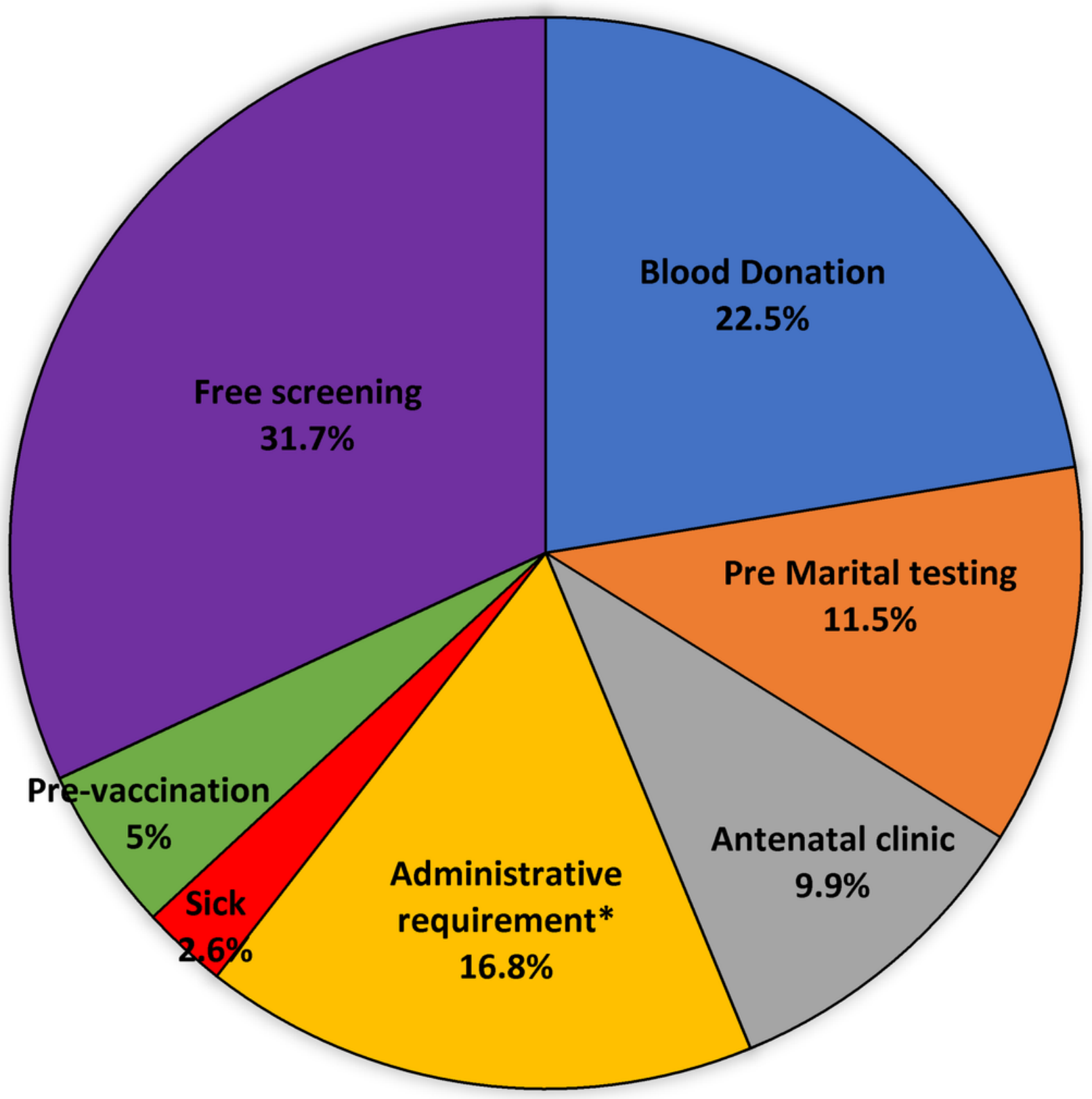

*Mandatory requirements for a job acquisition, immigration and academic admissions Figure 2

Reasons for first HBV testing for HBV infected cases(n=212) 


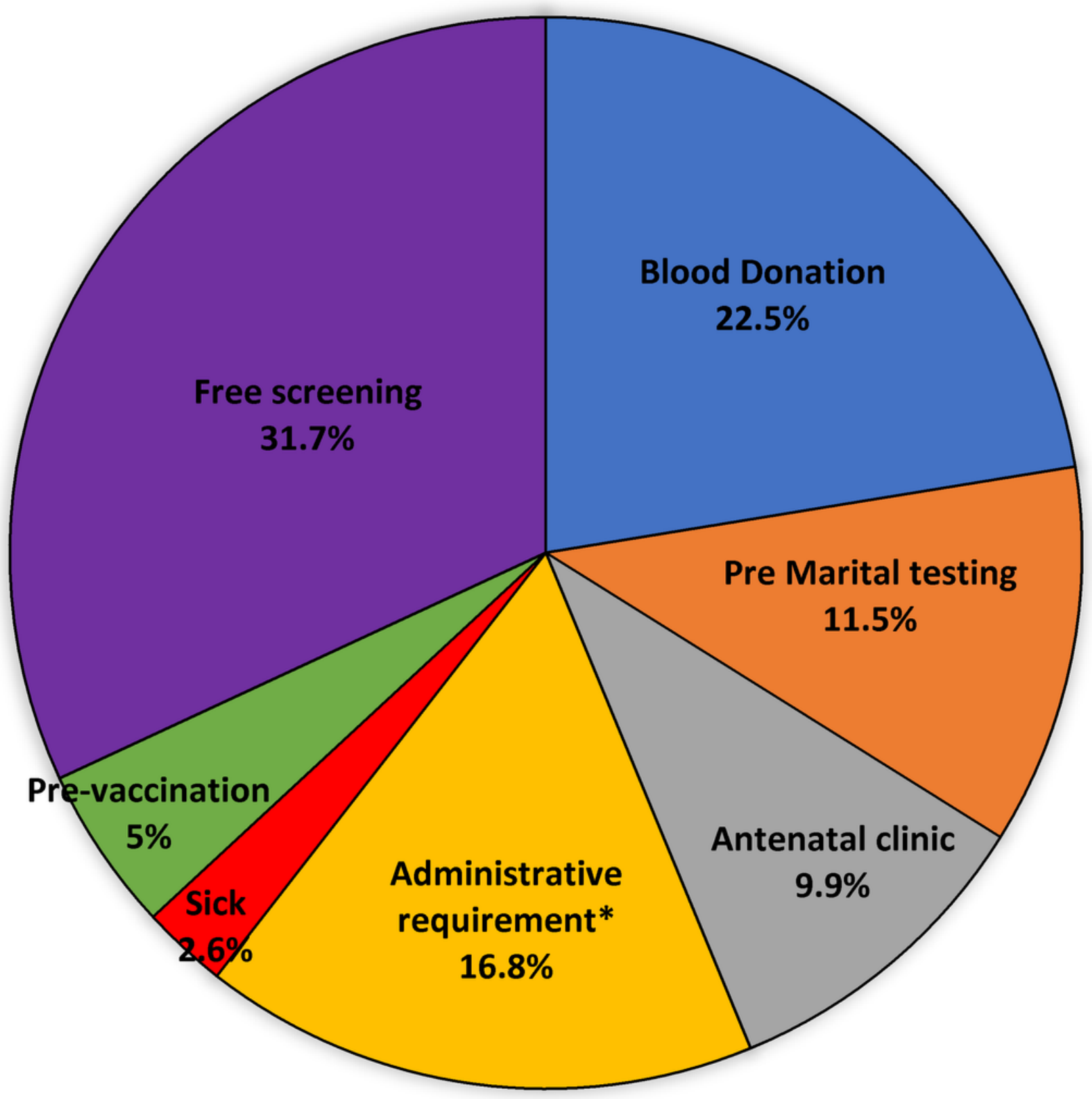

*Mandatory requirements for a job acquisition, immigration and academic admissions Figure 2

Reasons for first HBV testing for HBV infected cases(n=212) 